\title{
ANALISIS PENURUNAN TARIF PAJAK PENGHASILAN BADAN TERHADAP KEEKONOMIAN KONTRAK BAGI HASIL GROSS SPLIT DAN MULTIPLIER EFFECT BAGI PEREKONOMIAN PADA KEGIATAN HULU MINYAK BUMI DI INDONESIA
}

\author{
Gregorius Bela Prasetya
}

Direktorat Jenderal Pajak. Email: gregoriusbela.prasetya@pajak.go.id

\section{ABSTRACT}

Analysis of declining income tax rate of economics on production sharing contract gross split and multiplier effect for the economy in upstream activity in Indonesia describes about Indonesia's Government announces regulation of production sharing contract gross split in upstream activity for contractor to invest in oil and gas in Indonesia. Due to the pandemic of COVID-19, the Government of Indonesia announced another regulation in regard to income tax rate reduction. This has positively affected the economics on NPV and IRR of contractor and has triggered multiplier effects for the economy in general. Sensitivity analysis is used to calculate the effect of income tax rate reduction for the economics in gross split and multiplier effect. This research has shown that $1 \%$ of declining income tax rate affects US $\$ 29,333,000$ of NPV, 0.3\% of IRR, US $\$ 20,533,000$ Gross Domestic Product and 2,933 jobs in pessimistic scenario; US $\$ 61,107,000$ of NPV, $0.5 \%$ of IRR, US $\$ 42,775,000$ Gross Domestic Product and 6,171 jobs in moderate scenario; and US\$92,881,000 of NPV, 0.6\% of IRR, US\$65,016,000 Gross Domestic Product and 9,288 jobs in optimistic scenario.

\section{ABSTRAK}

Analisis penurunan tarif pajak penghasilan badan terhadap keekonomian kontrak bagi hasil gross split dan multiplier effect pada kegiatan hulu minyak bumi di Indonesia menjelaskan bahwa pemerintah Indonesia mengeluarkan kebijakan mengenai kontrak bagi hasil dengan skema gross split untuk kontraktor melakukan investasi pada kegiatan hulu minyak bumi. Adanya pandemi COVID-19, pemerintah mengeluarkan kebijakan lain berupa insentif penurunan tarif pajak penghasilan yang berpengaruh positif terhadap keekonomian pada NPV dan IRR atas kontrak yang dimiliki kontraktor dan menyebabkan multiplier effect untuk ekonomi secara umum. Analisis sensitivitas digunakan untuk menghitung dampak atas penurunan tarif pajak penghasilan terhadap keekonomian kontrak bagi hasil gross split dan multiplier effect. Hasil penelitian menunjukkan bahwa penurunan tarif pajak penghasilan sebesar 1\% akan 
berdampak pada penambahan NPV sebesar US $\$ 29.333 .000$, peningkatan IRR sebesar 0,3\%, penambahan Produk Domestik Bruto sebesar US\$20.533.000 dan 2.933 lapangan pekerjaan dalam skenario pesimis; penambahan NPV sebesar US\$61.107.000, peningkatan IRR sebesar 0,5\%, penambahan Produk Domestik Bruto sebesar US\$42.775.000 dan 6.111 lapangan pekerjaan pada skenario moderat; dan penambahan NPV sebesar US92.881.000, peningkatan IRR sebanyak 0,6\%, penambahan Produk Domestik Bruto sebesar US\$65.016.000 dan 9.288 lapangan pekerjaan pada skenario optimis.

Kata kunci: Tarif pajak, keekonomian, gross split, multiplier effect

\section{PENDAHULUAN}

\subsection{Latar Belakang}

Undang-Undang Dasar Negara Republik Indonesia 1945 Pasal 33 Ayat 3 mengamanahkan negara untuk dapat menguasai bumi, air, dan kekayaan alam yang terkandung di dalam bumi Indonesia untuk digunakan sebesarbesarnya bagi kemakmuran rakyat. Minyak bumi merupakan salah satu kekayaan alam yang ada dan memiliki nilai ekonomis di bumi Indonesia.

Minyak bumi menjadi salah satu penyumbang pendapatan negara. Pajak penghasilan minyak dan gas bumi (migas) menjadi salah satu komponen dalam postur penerimaan negara. Selain itu kegiatan usaha migas memiliki dampak berganda (multiplier effect) bagi perekonomian baik untuk sekitar wilayah kerja maupun secara nasional.

Studi kasus yang dilakukan oleh Pusat Data dan Informasi Kementerian Energi dan Sumber Daya Mineral (Pusdatin, ESDM) pada tahun 2016 menyimpulkan bahwa kegiatan usaha hulu migas berdampak signifikan pada perekonomian, pembangunan sumber daya manusia, dan pembangunan infrastruktur di regional wilayah kerja (Kabupaten Tanjung Jabung Timur).

Di Indonesia, investasi di sektor migas dibagi menjadi dua kegiatan usaha besar yakni hulu dan hilir. Pasal 1 Undang-Undang Nomor 22 Tahun 2001 tentang Minyak dan Gas Bumi menjelaskan bahwa kegiatan usaha hulu bertumpu pada eksplorasi dan eksploitasi, sedangkan kegiatan usaha hilir bertumpu pada pengolahan, pengangkutan, penyimpanan, dan/atau niaga. Menurut laporan tahunan Direktorat Jenderal Minyak dan Gas Bumi Kementerian Energi dan Sumber Daya Mineral (Ditjen Migas, ESDM) tahun 2019, lebih dari 80\% investasi sektor minyak bumi berada pada kegiatan usaha hulu.

Minyak bumi merupakan sumber daya alam yang tak terbarukan, sehingga jumlah cadangannya pun mengalami penurunan dari tahun ke tahun. Produksi minyak bumi di Indonesia pun semakin menurun setiap tahun. Berdasarkan data dari Ditjen Migas ESDM realisasi produksi minyak bumi pada akhir tahun 2019 sebesar 745.000 barel per hari. Sedangkan pada kuartal pertama tahun 2020 menjadi 701.000 barel per hari. Menurut Ditjen Migas ESDM, 
penurunan produksi minyak bumi disebabkan oleh penurunan kondisi cadangan secara alami (natural decline) dan belum ditemukannya cadangan besar yang menggantikan cadangan yang terus diproduksi.

Pemerintah Indonesia, melalui Kementerian ESDM dan Satuan Kerja Khusus Pelaksana Kegiatan Usaha Hulu Minyak dan Gas Bumi (SKK Migas) mengatur dan menjalin kontrak kerja sama dengan para kontraktor yang bergerak di sektor hulu minyak bumi. Kontrak kerja sama tersebut bertujuan untuk memproduksi minyak dari wilayah kerja yang sudah ada dan menemukan cadangan minyak baru. Kementerian ESDM dan SKK Migas melakukan berbagai upaya untuk menarik minat para kontraktor agar berinvestasi di wilayah Indonesia.

Pada tahun 2017, Kementerian ESDM mengeluarkan Peraturan Menteri Energi dan Sumber Daya Mineral Republik Indonesia Nomor 08 Tahun 2017 (Permen ESDM 08/2017) tentang Kontrak Bagi Hasil Gross Split. Kontrak bagi hasil gross split menggunakan mekanisme bagi hasil awal (base split) yang dapat disesuaikan berdasarkan komponen variabel dan progresif. Split yang diberikan dalam komponen variabel dan progresif berdasarkan kondisi wilayah kerja dan faktor lainnya seperti harga minyak dan gas bumi. Split yang diberikan berpengaruh terhadap keekonomian suatu kegiatan hulu migas. Kontraktor akan melakukan investasi jika mencapai keekonomian tertentu.

Pasal 5 ayat (1) Permen ESDM 08/2017 mencantumkan bahwa dalam pelaksanaan kontrak bagi hasil gross split ditetapkan besaran bagi hasil awal (base split) 57\% dari total produksi bagian negara dan 43\% dari total produksi bagian kontraktor. Permen ESDM 8/2017 ini juga mengatur mengenai penerimaan negara dan kontraktor. Penerimaan negara dalam kontrak bagi hasil gross split terdiri atas bagian negara, pajak penghasilan kontraktor, pajak tidak langsung dan bonus. Sedangkan penerimaan kontraktor dihitung berdasarkan persentase gross produksi setelah dikurangi pajak penghasilan.

Pada bulan Agustus 2017, Kementerian ESDM mengeluarkan Peraturan Menteri Energi dan Sumber Daya Mineral Nomor 52 Tahun 2017 tentang Perubahan atas Peraturan Menteri Energi dan Sumber Daya Mineral Republik Indonesia Nomor 08 Tahun 2017 tentang Kontrak Bagi Hasil Gross Split (Permen ESDM 52/2017). Dalam Permen ESDM 52/2017 disebutkan bahwa biaya operasi yang telah dikeluarkan oleh kontraktor dapat diperhitungkan sebagai unsur pengurang pajak penghasilan kontraktor. Besarnya pajak penghasilan kontraktor dihitung berdasarkan penghasilan kena pajak dikalikan dengan tarif pajak sesuai Undang-Undang Nomor 36 Tahun 2008 tentang Perubahan Keempat atas UndangUndang Nomor 7 Tahun 1983 tentang Pajak Penghasilan (UU 36/2008). Menurut data Kementerian ESDM sampai dengan 2019 sudah 40 kontrak kerja sama menggunakan skema gross split.

Namun pada awal tahun 2020 muncul pandemi corona virus disease 2019 (COVID-19) yang melanda 
seluruh dunia. Pandemi tersebut juga berdampak pada perekonomian. Untuk mengatasi dampak yang terjadi, Pemerintah Indonesia menerbitkan Undang-Undang Republik Indonesia Nomor 2 Tahun 2020 tentang Penetapan Peraturan Pemerintah Pengganti Undang-Undang Nomor 1 Tahun 2020 tentang Kebijakan Keuangan Negara Dan Stabilitas Sistem Keuangan Untuk Penanganan Pandemi Corona Virus Disease 2019 (COVID-19) Dan/Atau Dalam Rangka Menghadapi Ancaman yang Membahayakan Perekonomian Nasional Dan/Atau Stabilitas Sistem Keuangan Menjadi Undang-Undang.

Atas pertimbangan tersebut, Pemerintah juga menerbitkan Peraturan Pemerintah Nomor 30 Tahun 2020 (PP30/2020) tentang Penurunan Tarif Pajak Penghasilan Bagi Wajib Pajak Badan Dalam Negeri yang Berbentuk Perseroan Terbuka. Berdasarkan latar belakang yang telah diuraikan, tarif pajak penghasilan menjadi salah satu faktor pertimbangan kontraktor untuk berinvestasi di Indonesia. Penelitian ini bertujuan untuk menganalisis dampak penurunan tarif pajak penghasilan terhadap kegiatan hulu minyak bumi yang menggunakan kontrak bagi hasil gross split dan multiplier effect bagi perekonomian di Indonesia.

\subsection{Rumusan Masalah}

Berdasarkan latar belakang sebagaimana telah diuraikan pada bagian 1.1, penulis merumuskan dua masalah utama yang dibahas dalam penelitian ini, yaitu:
1. dampak penurunan tarif pajak penghasilan badan dalam negeri terhadap keekonomian kontraktor kegiatan usaha hulu minyak bumi yang menggunakan kontrak bagi hasil gross split di Indonesia. Keekonomian diukur dari analisis sensitivitas dengan menggunakan indikator Net Present Value (NPV) dan Internal Rate of Return (IRR).

2. dampak penurunan tarif pajak penghasilan terhadap multiplier effect bagi perekonomian yang diakibatkan oleh kegiatan hulu minyak bumi di Indonesia.

\subsection{Tujuan Penelitian}

Penelitian ini memiliki dua tujuan yang ingin dicapai, yaitu:

1. untuk mengetahui dampak penurunan tarif pajak penghasilan badan dalam negeri terhadap keekonomian kontraktor kegiatan usaha hulu minyak bumi yang menggunakan kontrak bagi hasil gross split di Indonesia.

2. untuk mengetahui dampak dari penurunan tarif pajak penghasilan terhadap multiplier effect bagi perekonomian yang diakibatkan oleh kegiatan hulu minyak bumi di Indonesia.

\section{KERANGKA TEORETIS DAN PENGEMBANGAN HIPOTESIS}

\subsection{Penurunan Tarif Pajak Penghasilan Badan}

Penentuan tarif pajak merupakan salah satu alat pemerintah dalam menentukan 
dasar pemungutan pajak. Penentuan tarif pajak penghasilan harus memenuhi asas keadilan. Tarif pajak yang ditetapkan terlalu rendah dapat menyebabkan penerimaan pajak tidak dapat memenuhi kebutuhan pembiayaan pembangunan. Namun jika terlalu tinggi dapat menyebabkan perlambatan pergerakan ekonomi karena beban Wajib Pajak terlalu besar. Oleh karena itu, tarif pajak tidak hanya didasari pada seberapa besar jumlah pajak yang dapat dibayar oleh Wajib Pajak, tetapi juga harus mempertimbangkan seberapa besar jumlah pajak yang ingin dibayar oleh Wajb Pajak (Hidayat, 2014).

Tarif pajak penghasilan badan dalam negeri yang berlaku sampai dengan Tahun Pajak 2019 sebesar 25\%. Guna memulihkan perekonomian akibat pandemi COVID-19, pemerintah memberikan insentif perpajakan. Insentif tersebut dalam bentuk penurunan tarif pajak penghasilan untuk wajib pajak badan dalam negeri. Penurunan tarif pajak penghasilan tersebut akan dilakukan bertahap. Berdasarkan pasal 2 PP30/2020, tarif pajak penghasilan yang diterapkan atas penghasilan kena pajak bagi Wajib Pajak badan dalam negeri dan bentuk usaha tetap sebesar 22\% yang berlaku pada Tahun Pajak 2020 dan Tahun Pajak 2021, serta 20\% yang mulai berlaku pada Tahun Pajak 2022. Wajib Pajak dalam negeri dapat memperoleh tambahan penurunan tarif sebesar 3\% jika memenuhi persyaratan tertentu yang diatur dalam PP30/2020.

Tarif pajak penghasilan dalam PP30/2020 akan menggantikan tarif pajak pada pasal 17 Undang-Undang
Nomor 36 Tahun 2008 tentang Perubahan Keempat atas UndangUndang Nomor 7 Tahun 1983 tentang Pajak Penghasilan (UU 36/2008). Tarif pajak penghasilan sebesar 28\% menjadi 25\% pada Tahun Pajak 2010. Penurunan tarif pajak penghasilan tersebut belum dapat meningkatkan penerimaan pajak penghasilan badan karena hanya meningkatkan jumlah wajib pajak terdaftar saja namun tidak diikuti dengan meningkatnya kepatuhan dan kesadaran wajib pajak badan dalam melaksanakan kewajiban perpajakannya (Hani dan Daoed, 2013).

\subsection{Pajak Penghasilan Kontrak Bagi Hasil Gross Split}

Salah satu pertimbangan kontraktor terhadap suatu wilayah adalah prospek geologi serta ketentuan perpajakannya (Lubiantara, 2012). Pajak penghasilan untuk kegiatan usaha hulu migas dengan kontrak bagi hasil gross split mengacu pada Peraturan Pemerintah Nomor 53 Tahun 2017 tentang Perlakuan Perpajakan pada Kegiatan Usaha Hulu Minyak dan Gas Bumi dengan Kontrak Bagi Hasil Gross Split (PP53/2017).

\section{Pasal 4 ayat (1) PP53/2017} membagi penghasilan bruto kontraktor menjadi dua komponen. Komponen pertama ialah penghasilan dalam rangka bagi hasil migas. Penghasilan bagi hasil migas dihitung berdasarkan nilai realisasi migas bagian kontraktor dikurangi nilai realisasi penyerahan Domestic Market Obligation (DMO). Berdasarkan Pasal 1 PP53/2017, DMO adalah kewajiban penyerahan bagian kontraktor berupa 
minyak dan/atau gas bumi untuk memenuhi kebutuhan dalam negeri. Pasal 17 ayat (2) PP53/2017 menyatakan bahwa kontraktor wajib menyerahkan DMO sebesar 25\% dari bagiannya.

$$
\text { Komponen kedua dari }
$$

penghasilan bruto kontraktor ialah penghasilan lainnya selain dalam rangka bagi hasil migas. Penghasilan lainnya meliputi penghasilan yang berasal dari uplift, pengalihan Partisipasi Interes, hasil penjualan produk sampingan kegiatan usaha hulu, dan penghasilan lain yang memberikan tambahan kemampuan ekonomis. Penghasilan kontraktor untuk kontrak bagi hasil gross split berdasarkan pasal 14 PP53/2017 diakui pada titik penyerahan.

$$
\text { Pasal } 5 \text { ayat (1) PP53/2017 }
$$
mengatur biaya operasi yang digunakan sebagai unsur pengurang penghasilan kontraktor dalam rangka bagi hasil migas untuk penghitungan penghasilan kena pajak. Biaya operasi terdiri dari biaya eksplorasi, biaya eksploitasi, dan biaya lainnya. Biaya eksplorasi meliputi biaya pengeboran eksplorasi, biaya umum dan administrasi selama kegiatan eksplorasi, serta biaya penelitian geologis dan geofisika. Biaya eksploitasi meliputi biaya pengeboran pengembangan, biaya langsung produksi migas, biaya pemrosesan gas bumi, biaya utility (biaya perangkat produksi dan pemeliharaan peralatan, serta biaya uap, air, dan listrik), biaya umum dan administrasi selama kegiatan eksploitasi, biaya penyusutan, serta biaya amortisasi. Biaya lainnya meliputi biaya untuk memindahkan migas dari titik produksi ke titik penyerahan, biaya kegiatan pascaoperasi kegiatan usaha hulu, biaya pemasaran migas yang telah disetujui Kepala SKK Migas, biaya penggantian investasi kepada kontraktor sebelumnya, serta biaya lain yang terkait dengan kegiatan usaha hulu.

Penghasilan neto kontraktor untuk satu tahun pajak diatur dalam pasal 18 ayat (1) PP53/2017. Penghasilan neto kontraktor didapatkan dari penghasilan dalam rangka bagi hasil migas ditambah penghasilan lainnya, berasal dari hasil penjualan produk sampingan dan penghasilan lain yang memberikan tambahan kemampuan ekonomis, dikurangi biaya operasi, biaya pembentukan dan pemupukan dana cadangan, serta pajak penghasilan karyawan yang ditanggung kontraktor, kecuali yang dibayarkan sebagai tunjangan pajak.

Jika kontraktor mengalami kerugian, maka dapat dikompensasikan hingga 10 (sepuluh) tahun pajak berikutnya berturut-turut sesuai dengan pasal 18 ayat (2) PP 53/2017. Penghasilan kena pajak kontraktor didapatkan dari penghasilan neto dikurangi kompensasi kerugian. Besarnya pajak penghasilan kontraktor dihitung berdasarkan penghasilan kena pajak dikalikan dengan tarif pajak sesuai ketentuan yang berlaku.

\subsection{Analisis Sensitivitas}

Analisis sensitivitas adalah suatu metode yang digunakan untuk melihat seberapa besar pengaruh perubahan dari suatu parameter terhadap indikator keekonomian (Pramadika dan Satiyawira, 2018). Dalam kontrak bagi hasil 
gross split, segala biaya yang dikeluarkan menjadi tanggung jawab kontraktor. Sehingga kontraktor harus memperhitungkan antara kebutuhan biaya investasi dan proyeksi penerimaan. Keekonomian pada kegiatan hulu migas dijadikan salah satu pertimbangan untuk membuat keputusan investasi (Pudyantoro, 2014).

\section{Ukuran-ukuran}

keekonomian

yang digunakan dalam pengambilan keputusan investasi hulu minyak bumi antara lain net present value (NPV) dan internal rate of return (IRR). NPV merupakan nilai sekarang yang dihitung dengan mendiskonkan aliran kas bersih proyek menggunakan tingkat diskonto (discount rate) tertentu. IRR merupakan tingkat bunga tertentu yang menyebabkan aliran kas masuk sama dengan aliran kas keluar. Suatu investasi dapat dilakukan jika NPV bernilai positif atau lebih besar dari 0 dan IRR lebih besar dari tingkat diskonto yang digunakan. Analisis sensitivitas digunakan untuk menentukan perkiraan NPV dan IRR dari sebuah proyek yang dipengaruhi oleh perubahan salah satu variabel masukan (Saltelli dalam Erwinsyah, 2012).

\subsection{Multiplier Effect Kegiatan Usaha Hulu Migas}

Multiplier effect adalah salah satu mekanisme dasar pembangunan lokal dan regional ketika salah satu jenis kegiatan ekonomi mempengaruhi yang lainnya. Semakin besar pemanfaatan industri migas terhadap penggunaan tenaga kerja, komponen, dan industri penunjang dalam negeri, maka semakin besar pertumbuhan dan pembangunan ekonomi secara keseluruhan.

Kegiatan usaha hulu migas menciptakan multiplier effects pada ekonomi nasional, baik yang berdampak secara langsung, tidak langsung, maupun induksi (The Boston Consulting Group dalam katadata.co.id, 2020). Secara langsung dirasakan oleh kegiatan usaha penunjang kegiatan hulu migas. Secara tidak langsung berdampak pada sektor transportasi, industri hilir, informasi dan teknologi, ekonomi di sekitar lokasi wilayah kerja migas, dan lainnya. Secara induksi dirasakan pada sektor utilitas, infrastruktur, keamanan nasional dan lainnya.

Hasil studi SKK Migas bersama Universitas Indonesia tahun 2015 yang dipublikasikan pada Laporan Tahunan SKK Migas tahun 2017 menyatakan bahwa setiap investasi sebesar US\$1.000.000 pada industri hulu migas mampu meningkatkan Produk Domestik Bruto (PDB) sebesar US\$700.000 dan membuka lapangan kerja baru untuk 100 orang.

\section{METODOLOGI PENELITIAN}

Metode penelitian diartikan sebagai cara ilmiah untuk mendapatkan data dengan tujuan dan kegunaan tertentu (Sugiyono, 2016a). Penelitian ini menggunakan metode kualitatif. Penelitian kualitatif digunakan untuk meneliti kondisi obyek yang alamiah dan memahami makna di balik data yang tampak (Sugiyono, 2016b). Penelitian kualitatif dibagi ke dalam lima pendekatan, yakni studi naratif, studi fenomonologi, 
studi grounded theory, studi etnografis, dan studi kasus (Cresswell, 2013). Pendekatan dalam penelitian ini adalah penelitian kualitatif dengan pendekatan studi kasus. Pendekatan studi kasus dipilih karena penelitian fokus pada dampak penurunan tarif pajak penghasilan terhadap keekonomian kontrak bagi hasil gross split.

Jenis data yang digunakan dalam penelitian ini ialah data sekunder. Data tersebut didapatkan dari penelitian kepustakaan berupa peraturan, buku, jurnal dan penelitian ilmiah yang berkaitan dengan penurunan tarif pajak penghasilan dan kegiatan usaha hulu minyak dengan kontrak bagi hasil gross split. Data perkiraan produksi sumur untuk melakukan analisis sensitivitas keekonomian lapangan diambil dari proyek-proyek utama yang ada di Indonesia. Berdasarkan laporan realisasi produksi minyak SKK Migas per Mei 2020, rata-rata produksi dari 15 proyek utama mencapai 44.083 barel per hari

Untuk menentukan analisis sensitivitas keekonomian, perlu membagi perkiraan produksi dalam tiga skenario (Sudono dan Prasetyo, 2017). Pertama, skenario moderat yaitu perkiraan kemampuan produksi berdasarkan data rata-rata dari proyek utama di Indonesia. Kedua, skenario pesimis yaitu perkiraan kemampuan produksi diasumsikan hanya setengah (50\%) dari kemampuan skenario moderat atau sebesar 22.042 barel per hari. Ketiga, skenario optimis yaitu perkiraan kemampuan produksi diasumsikan satu setengah (150\%) dari kemampuan skenario moderat atau sebesar 66.124 barel per hari.
Setelah mendapatkan data gross produksi minyak, langkah selanjutnya menentukan split kontraktor dan pemerintah berdasarkan perkiraan gambaran wilayah kerja. Kemudian, kontraktor juga menentukan biaya operasi untuk mendapatkan penghasilan kena pajak. Penghasilan kena pajak dari kontraktor akan dikalikan dengan besaran tarif pajak pada UU36/2008 dan PP30/2020. Hasilnya akan dibandingkan dengan tiga skenario yang digunakan. Penghasilan pajak yang diterima dari kontraktor merupakan salah satu penambahan pendapatan negara. Dari sisi kontraktor, penghasilan setelah dikurangi pajak dijadikan dasar penghitungan NPV dan IRR. Perubahan NPV akibat penurunan tarif pajak penghasilan dijadikan dasar untuk penghitungan multiplier effect bagi perekonomian seperti yang diuraikan pada bagian sebelumnya.

\section{HASIL DAN PEMBAHASAN}

Analisis penurunan tarif pajak penghasilan terhadap keekonomian suatu lapangan dengan kontrak bagi hasil gross split membutuhkan parameter dalam penghitungannya. Parameter yang digunakan dalam penelitian ini ditunjukkan pada Tabel 1. 
Tabel 1 Parameter yang digunakan

Sumber: diolah penulis dari berbagai sumber (2020)

\begin{tabular}{|c|l|c|}
\hline No & \multicolumn{1}{|c|}{ Parameter } & Besaran \\
\hline 1 & Tarif Pajak Penghasilan (1) & $25 \%$ \\
\hline 2 & Tarif Pajak Penghasilan (2) & $22 \%$ \\
\hline 3 & Tarif Pajak Penghasilan (3) & $20 \%$ \\
\hline 4 & Periode pengembangan wilayah kerja & 3 Tahun \\
\hline 5 & Periode eksploitasi & 20 Tahun \\
\hline 6 & Biaya investasi kapital & US $\$ 475.000 .000$ \\
\hline 7 & Biaya operasional & $40 \%$ dari produksi \\
\hline 8 & Tingkat diskonto & $10 \%$ \\
\hline 9 & DMO & $25 \%$ \\
\hline
\end{tabular}

Sebelum penghitungan keekonomian dilakukan, perlu ditentukan dahulu nilai split kontraktor. Base split untuk produksi minyak bumi sebesar 43\%, ditambah dengan split dari komponen variabel dan progresif dari salah satu wilayah kerja yang ada di Indonesia. Komponen variabel dan progresif yang digunakan dalam penelitian ini ditunjukkan pada Tabel 2.

Tabel 2 Komponen Variabel dan Progresif

Sumber: Permen ESDM 52/2017 dan data WK Migas Kementerian ESDM (2020)

\begin{tabular}{|c|l|c|c|}
\hline No & \multicolumn{1}{|c|}{ Karakteristik } & Kondisi & Split \\
\hline 1 & Status lapangan & POD I & $5 \%$ \\
\hline 2 & Lokasi lapangan $(\mathrm{m})$ & Onshore & $0 \%$ \\
\hline 3 & Kedalaman reservoir $(\mathrm{m})$ & $>2500$ & $1 \%$ \\
\hline 4 & Ketersediaan infrastruktur pendukung & Well developed & $0 \%$ \\
\hline 5 & Jenis reservoir & Konvensional & $0 \%$ \\
\hline 6 & Kandungan $\mathrm{CO}_{2}$ & $<5 \%$ & $0 \%$ \\
\hline 7 & Kandungan $\mathrm{H}_{2} \mathrm{~S}$ & $<100$ & $0 \%$ \\
\hline 8 & Specifi Gravity & $<25$ & $1 \%$ \\
\hline 9 & TKDN & $50 \leq x<70$ & $3 \%$ \\
\hline 10 & Tahapan produksi & Primer & $0 \%$ \\
\hline 11 & Harga minyak (US\$ per barel) & 41,6 & $10,85 \%$ \\
\hline 12 & Jumlah kumulatif produksi & $\geq 175$ & $0 \%$ \\
\hline
\end{tabular}




\subsection{Analisis Sensitivitas Penurunan Tarif Pajak terhadap NPV}

Analisis sensitivitas dilakukan dengan menggunakan tarif pajak berdasarkan UU36/2008 dan PP30/2020 terhadap NPV dari kontraktor. Sensitivitas beberapa tarif pajak dengan NPV kontraktor dengan kontrak bagi hasil gross split skenario pesimis, moderat, dan optimis pengembangan lapangan minyak ditunjukkan dalam Grafik 1.

Grafik 1. Analisis Sensitivitas Penurunan Tarif Pajak terhadap NPV (US\$) Sumber: Diolah penulis dari data dan simulasi (2020)

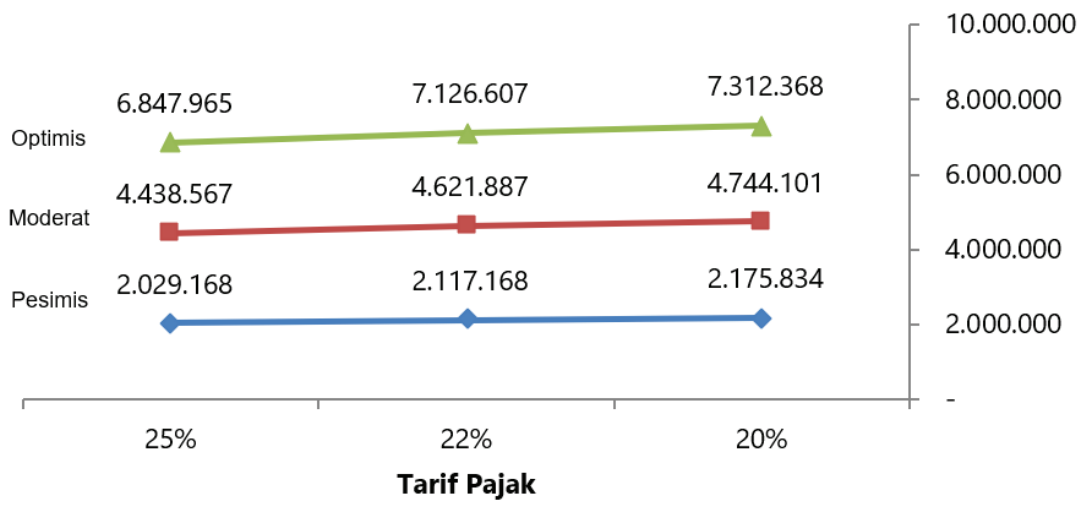

Penurunan tarif pajak penghasilan badan dari 25\% menjadi 22\% pada skenario pesimis akan menambah NPV sebesar US\$88.000.000. Penurunan tarif pajak penghasilan badan dari $22 \%$ menjadi $20 \%$ pada skenario pesimis akan menambah NPV sebesar US\$58.667.000. Rata-rata penurunan 1\% dari tarif pajak penghasilan pada skenario pesimis akan menambah NPV sebesar US\$29.333.000.

Pada skenario moderat, penurunan tarif pajak penghasilan badan dari 25\% menjadi 22\% akan menambah NPV sebesar US\$183.821.000. Penurunan tarif pajak penghasilan badan dari 22\% menjadi 20\% pada skenario moderat akan menambah NPV sebesar US\$122.214.000. Rata-rata penurunan 1\% dari tarif pajak penghasilan pada skenario moderat akan menambah NPV sebesar US\$61.107.000.

Dengan skenario optimis, penurunan tarif pajak penghasilan badan dari 25\% menjadi 22\% akan menambah NPV sebesar US\$278.642.000. Penurunan tarif pajak penghasilan badan dari 22\% menjadi 20\% pada skenario optimis akan menambah NPV sebesar US\$185.761.000. Rata-rata penurunan 1\% dari tarif pajak penghasilan pada skenario optimis akan menambah NPV sebesar US\$92.881.000.

Penurunan tarif pajak penghasilan badan berbanding terbalik dengan kenaikan NPV kontraktor dengan kontrak bagi hasil gross split. Semakin turun tarif pajak penghasilan akan semakin menambah NPV kontraktor. 


\subsection{Analisis Sensitivitas Penurunan Tarif Pajak terhadap IRR}

Sensitivitas beberapa tarif pajak dengan IRR kontraktor dengan kontrak bagi hasil gross split skenario pesimis, moderat, dan optimis pengembangan lapangan minyak ditunjukkan dalam Grafik 2.

Grafik 2. Analisis Sensitivitas Penurunan Tarif Pajak terhadap IRR

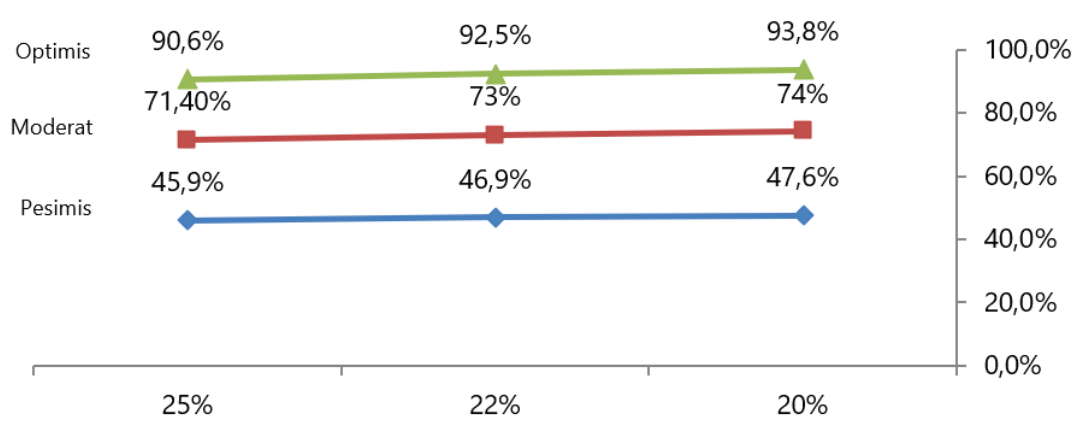

Sumber: Diolah penulis dari data dan simulasi (2020)

Penurunan tarif pajak penghasilan badan dari 25\% menjadi 22\% pada skenario pesimis akan meningkatkan IRR sebanyak 1\%. Penurunan tarif pajak penghasilan badan dari 22\% menjadi 20\% pada skenario pesimis akan meningkatkan IRR sebanyak 0,7\%. Rata-rata penurunan 1\% dari tarif pajak penghasilan pada skenario pesimis akan meningkatkan IRR sebanyak 0,3\%.

Pada skenario moderat, penurunan tarif pajak penghasilan badan dari 25\% menjadi 22\% akan meningkatkan IRR sebanyak 1,6\%. Penurunan tarif pajak penghasilan badan dari 22\% menjadi 20\% pada skenario moderat akan meningkatkan IRR kontraktor sebanyak 1\%. Rata-rata penurunan $1 \%$ dari tarif pajak penghasilan pada skenario moderat akan meningkatkan IRR sebanyak 0,5\%.

Pada skenario optimis, penurunan tarif pajak penghasilan badan dari 25\% menjadi 22\% akan meningkatkan IRR sebanyak 1,9\%. Penurunan tarif pajak penghasilan badan dari 22\% menjadi 20\% pada skenario optimis akan meningkatkan IRR sebanyak 1,2\%. Rata-rata penurunan 1\% dari tarif pajak penghasilan pada skenario optimis akan meningkatkan IRR sebanyak 0,6\%.

Penurunan tarif pajak penghasilan badan berbanding terbalik dengan peningkatan IRR kontraktor dengan kontrak bagi hasil gross split. Semakin turun tarif pajak penghasilan akan semakin meningkat IRR kontraktor.

\subsection{Analisis Penurunan Tarif Pajak terhadap Multiplier Effect Kegiatan Usaha Hulu Minyak Bumi}

Multiplier effect atas kegiatan usaha hulu minyak bumi dihitung berdasarkan hasil studi bersama SKK Migas dengan Universitas Indonesia pada tahun 2015. Penurunan tarif pajak penghasilan akan menambah NPV kontraktor. Dapat diartikan bahwa kontraktor memiliki surplus untuk diinvestasikan dalam kegiatan usahanya.

Pada skenario pesimis, rata-rata penurunan $1 \%$ dari tarif pajak penghasilan akan menambah NPV sebesar US\$29.333.000. Jika atas penambahan NPV tersebut digunakan oleh kontraktor untuk diinvestasikan kembali maka akan meningkatkan PDB sebanyak US\$20.533.000 dan membuka lapangan pekerjaan bagi 2.933 orang.

Pada skenario moderat, rata-rata penurunan 1\% dari tarif pajak penghasilan akan menambah NPV sebesar US\$61.107.000. Jika atas penambahan NPV tersebut diinvestasikan oleh kontraktor akan 
meningkatkan PDB sebanyak US $\$ 42.775 .000$ dan membuka lapangan pekerjaan bagi 6.111 orang.

Pada skenario optimis, rata-rata penurunan $1 \%$ dari tarif pajak penghasilan akan menambah NPV sebesar US\$92.881.000. Jika atas penambahan NPV tersebut diinvestasikan oleh kontraktor akan meningkatkan PDB sebanyak US\$65.016.000 dan membuka lapangan pekerjaan bagi 9.288 orang.

\section{KESIMPULAN}

Produksi minyak di Indonesia semakin menurun. Investasi oleh kontraktor dalam kegiatan usaha hulu minyak masih sangat dibutuhkan pemerintah. Untuk meningkatkan investasi maka pemerintah menerbitkan kebijakan kontrak bagi hasil gross split dalam kerja sama dengan kontraktor. Kontrak bagi hasil gross split baru diberlakukan di tahun 2017. Namun pada awal tahun 2020 muncul pandemi COVID-19 yang berdampak pada perekonomian.

Untuk mengatasi dampak yang terjadi, pemerintah menerbitkan kebijakan, salah satunya ialah Peraturan Pemerintah Nomor 30 Tahun 2020 tentang Penurunan Tarif Pajak Penghasilan Bagi Wajib Pajak Badan Dalam Negeri yang Berbentuk Perseroan Terbuka. Tarif pajak penghasilan badan merupakan salah satu faktor pertimbangan kontraktor untuk melakukan investasi pada kegiatan hulu minyak bumi.

Penelitian ini melakukan penghitungan melalui analisis sensitivitas dengan tiga skenario berbeda antara penurunan tarif pajak penghasilan badan terhadap keekonomian kontrak bagi hasil gross split dengan menggunakan indikator NPV dan IRR. Hasil penelitian ini menunjukkan bahwa penurunan tarif pajak penghasilan badan berbanding terbalik dengan kenaikan NPV dan peningkatan IRR kontraktor dengan kontrak bagi hasil gross split. Semakin turun tarif pajak penghasilan akan semakin menambah NPV dan meningkatkan IRR kontraktor.

Pada skenario pesimis, rata-rata penurunan $1 \%$ dari tarif pajak penghasilan akan menambah NPV sebesar US\$29.333.000. Pada skenario moderat, rata-rata penurunan 1\% dari tarif pajak penghasilan akan menambah NPV sebesar US\$61.107.000. Pada skenario optimis, rata-rata penurunan 1\% dari tarif pajak penghasilan akan menambah NPV sebesar US\$92.881.000.

Pada skenario pesimis, rata-rata penurunan $1 \%$ dari tarif pajak penghasilan akan meningkatkan IRR sebanyak $0,3 \%$. Rata-rata penurunan $1 \%$ dari tarif pajak penghasilan pada skenario moderat akan meningkatkan IRR sebanyak 0,5\%. Pada skenario optimis, rata-rata penurunan 1\% dari tarif pajak penghasilan akan meningkatkan IRR sebanyak 0,6\%.

Selain itu, atas penurunan tarif pajak penghasilan badan menyebabkan penambahan NPV kontraktor yang dapat diinvestasikan kembali. Penginvestasian kembali atas penambahan NPV sebesar US\$29.333.000 pada skenario pesimis akan meningkatkan PDB sebanyak US\$20.533.000 dan membuka lapangan 
pekerjaan bagi 2.933 orang. Pada skenario moderat, penambahan NPV sebesar US\$61.107.000 akan meningkatkan PDB sebanyak US\$42.775.000 dan membuka lapangan pekerjaan bagi 6.111 orang. Pada skenario optimis penambahan NPV sebesar US\$92.881.000 akan meningkatkan PDB sebanyak US\$65.016.000 dan membuka lapangan pekerjaan bagi 9.288 orang.

\section{IMPLIKASI DAN KETERBATASAN}

Penelitian ini memiliki keterbatasan dalam penyusunannya. Penelitian hanya dilakukan pada kegiatan hulu minyak saja, sedangkan gas belum dibahas lebih lanjut. Simulasi perhitungan analisis sensitivitas terbatas pada indikator NPV dan IRR, sedangkan masih banyak faktor lain yang dijadikan pertimbangan kontraktor untuk menentukan keputusan investasi. Penelitian masih menggunakan data sekunder dan beberapa asumsi.

\section{DAFTAR PUSTAKA}

[1] Creswell, J. W. (2013). Qualitative inquiry \& research design: Choosing among five approaches (3rd ed.). California: Sage Publication.

[2] Erwinsyah. (2012). Analisis kelayakan proyek minyak dan gas (Studi kasus: Wilayah kerja Whiskey Alpha). Jakarta: Universitas Indonesia.

[3] Hani, S., \& Daoed, H. R. (2013). Analisis penurunan tarif PPh badan dalam meningkatkan penerimaan PPh di KPP Medan Barat. Jurnal Riset Akuntansi dan Bisnis, 13(1). https://doi.org/10.30596/jrab.v13i1.164

[4] Hidayat, A. (2014). Analisis dampak perubahan tarif pajak penghasilan di Indonesia. Jurnal BPPK, 7(1), 1-18. https://jurnal.bppk.kemenkeu.go.id/jurnalbppk/article/view/83

[5] Katadata. (2017). Inilah multiplier effect industri hulu migas. Katadata. Retrieved October 14, 2020, from https://databoks.katadata.co.id/datapublish/2017/12/13/inilah-multipliereffect-industri-hulu-migas

[6] Kementerian Energi dan Sumber Daya Mineral. (2019). Laporan tahunan 2019 Kementerian Energi dan Sumber Daya Mineral. Kementerian Energi dan Sumber Daya Mineral. Jakarta.

[7] Kementerian Keuangan Republik Indonesia (n.d.). APBN 2020. Kementerian Keuangan Republik Indonesia. Retrieved October 14, 2020, from https://www.kemenkeu.go.id/apbn2020

[8] Lubiantara, B. (2012). Ekonomi migas: Tinjauan aspek komersial kontrak migas. Jakarta: Grasindo.

[9] Peraturan Menteri Energi dan Sumber Daya Mineral Nomor 08 Tahun 2017 tentang Kontrak Bagi Hasil Gross Split.

[10] Peraturan Menteri Energi dan Sumber Daya Mineral Nomor 52 Tahun 2017 tentang Perubahan atas Peraturan Menteri Energi dan Sumber Daya Mineral Nomor 08 Tahun 2017 tentang Kontrak Bagi Hasil Gross Split.

[11] Peraturan Pemerintah Nomor 53 Tahun 2017 tentang Perlakuan Perpajakan pada Kegiatan Usaha Hulu Minyak dan Gas Bumi dengan Kontrak Bagi Hasil Gross Split 
[12] Peraturan Pemerintah Nomor 30 Tahun 2020 tentang tentang Penurunan Tarif Pajak Penghasilan Bagi Wajib Pajak Badan Dalam Negeri yang Berbentuk Perseroan Terbuka.

[13] Pramadika, H., \& Satiyawira, B. (2018). Pengaruh harga gas dan komponen variabel terhadap keuntungan kontraktor pada gross split. Jurnal Petro, VII (3). http://dx.doi.org/10.25105/petro.v7i3.3817

[14] Pudyantoro, A. R. (2014). Proyek hulu migas evaluasi dan analisis petroekonomi. Jakarta: Petromindo.

[15] Pusat Data dan Teknologi Informasi Kementerian Energi dan Sumber Daya Mineral. (2016). Dampak kegiatan usaha hulu migas terhadap perekonomian regional wilayah kerja migas (studi kasus Provinsi Jambi). Jakarta: Kementerian Energi dan Sumber Daya Mineral.

[16] Satuan Kerja Khusus Pelaksana Kegiatan Usaha Hulu Minyak dan Gas Bumi. (2017). Laporan tahunan 2017 SKK Migas. SKK Migas. Jakarta

[17] Sudono \& Prasetyo, A. (2017). Evaluasi kontrak pengembangan migas non konvensional di Indonesia. Jurnal Teknologi Minyak dan Gas Bumi, 14(2), 89-96.

[18] Sugiyono. (2016). Metode penelitian kuantitatif, kualitatif dan R\&D. Bandung: CV Alfabeta.

[19] Undang-Undang Republik Indonesia Nomor 22 Tahun 2001 tentang Minyak dan Gas Bumi.

[20] Undang-Undang Republik Indonesia Nomor 36 Tahun 2008 tentang Perubahan Keempat atas

[21] Undang-Undang Nomor 7 Tahun 1983 tentang Pajak Penghasilan

[22] Undang-Undang Republik Indonesia Nomor 2 Tahun 2020 tentang Penetapan Peraturan Pemerintah Pengganti Undang-Undang Nomor 1 Tahun 2020 tentang Kebijakan Keuangan Negara Dan Stabilitas Sistem Keuangan Untuk Penanganan Pandemi Corona Virus Disease 2019 (COVID-19) Dan/Atau Dalam Rangka Menghadapi Ancaman yang Membahayakan Perekonomian Nasional Dan/Atau Stabilitas Sistem Keuangan Menjadi Undang-Undang.

\section{LAMPIRAN}

Data Produksi Hulu Minyak

Sumber: Laporan Realisasi Produksi Minyak SKK Migas (2020)

\begin{tabular}{|c|c|c|}
\hline No & Wilayah & Produksi Minyak (bph) \\
\hline 1 & Mobil Cepu Ltd. & 220.234 \\
\hline 2 & PT Chevron Pacific Indonesia & 180.780 \\
\hline 3 & PT Pertamina EP & 80.722 \\
\hline 4 & Pertamina Hulu Mahakam & 30.725 \\
\hline 5 & Pertamina Hulu Energi ONWJ Ltd & 29.151 \\
\hline 6 & Pertamina Hulu Energi Oses & 26.941 \\
\hline 7 & Petrochina Internasional Jabung Ltd. & 16.413 \\
\hline 8 & Medco E\&P Natuna & 14.420 \\
\hline 9 & Pertamina Hulu Sanga Sanga & 11.911 \\
\hline 10 & Pertamina Hulu Kaltim & 10.647 \\
\hline 11 & BOB PT Bumi Siak Pusako - Pertamina Hulu & 9.332 \\
\hline 12 & Petronas Carigali (Ketapang) Ltd & 8.751 \\
\hline 13 & JOB PTM - Medco Tomori Sulawesi Ltd & 7.983 \\
\hline 14 & PT Medco E\&P Rimau & 6.777 \\
\hline 15 & Conocophillips (Grissik) Ltd & 6.465 \\
\hline & Total & $\mathbf{6 6 1 . 2 5 2}$ \\
\hline
\end{tabular}

